\title{
FOSSIL TIGER BEETLES (COLEOPTERA: CICINDELIDAE): REVIEW AND NEW QUATERNARY RECORDS
}

\author{
By Christopher D. Nagano ${ }^{1}$, Scott E. Miller ${ }^{2}$ \\ and Alan V. Morgan
}

INTRODUCTION

Fossil Cicindelidae are extremely rare in the stratigraphic record, probably due to the fragile nature of their exoskeleton. In this paper we summarize previous records and comment on new finds, as well as describe cicindelid specimens found in the southern California asphalt deposits which were noted, but not identified, by Pierce (1947a, 1947b).

\section{Southern California Asphalt Deposits}

Both the well known McKittrick asphalt deposit in Kern County, California and the Rancho La Brea sequence, Los Angeles County, California, have produced identifiable cicindelid specimens. Pierce's specimens are deposited in the Natural History Museum of Los Angeles County (LACM). A fairly well-preserved specimen of Cicindela haemorrhagica LeConte (LACM Invert. Paleo. hypotype 4944) from the McKittrick asphalt deposit, retains complete markings on the elytra, and the elytral pleura still show a blue coloration similar to that of populations found along the sea coast of central San Diego County, California. A mandible (LACM Invert. Paleo. hypotype 4945) also from McKittrick, is probably a cicindelid but family placement is uncertain due to the poor condition of the specimen. Both McKittrick specimens were collected by L. Bessom from W. D. Pierce's "site 4" (LACM Invert. Paleo. Loc. 260), at a depth of 4 feet (1.3m) (Pierce 1947b, Miller and Peck, 1979). This site has not yet been radiocarbon dated, but a Cybister elytron taken from a depth of 3 feet $(1 \mathrm{~m})$ in the road cut at McKittrick has provided an

\footnotetext{
'Natural History Museum of Los Angeles County, Los Angeles, California 90007. ${ }^{2}$ Museum of Comparative Zoology, Harvard University, Cambridge, Massachusetts 02138.

${ }^{3}$ Department of Earth Sciences, University of Waterloo, Waterloo, Ontario, Canada N2L 3G1.
}

Manuscript received by the editor May I, 1982. 
experimental sample for a ${ }^{14} \mathrm{C}$ mass spectrometer run at Chalk River Nuclear Laboratory, Ontario, Canada. The resultant age of $c a 8,000$ yr B.P. suggests that the samples are probably of Holocene age, (Miller and Peck 1979, Morgan and Morgan 1980a) or of very late Pleistocene age as stated by Pierce (1947b).

Three Cicindela specimens are known from Rancho La Brea; two thoraces of $C$. haemorrhagica (RLP 8779E and RLP 9014E) and a metasternum of $C$. oregona LeConte (RLP 9465E). RLP 8779E and 9465E are from Pierce's "Bliss 29" material, which was collected in 1929 by W. Bliss from the sites of pits A, B, and C. The samples are probably late Pleistocene in age, but this is questionable due to unknown locality and possible contamination (Miller and Peck, 1979). RLP 9014E is from Pierce's "Pit X", which refers to mixed material, lacking data, and of questionable age.

The Quaternary presence of C. haemorrhagica and C. oregona in southern California is not unexpected. Both are presently widely distributed in fresh and marine littoral habitats in western North America. Although these two species are not narrowly restricted to specific microhabitats, they are always found near permanent sources of water.

\section{New Records of Fossil Cicindelids Elsewhere in NORTh AMERICA}

Beside the above mentioned localities, a rekindled interest in the examination of coleopterous faunas has recently revealed fragments of cicindelids in a number of sites in the United States and Canada (Fig. 1). All but one of these records are more recent than the last review of North American fossil insects (Morgan and Morgan 1980b). The oldest specimen which is stratigraphically interpreted as pre last interglacial (pre-Sangamon) is a partial elytral fragment which is probably of the genus Omus from the Mountain View Dump site near Palo Alto, California (D. Adam pers. comm. 1978, Morgan unpublished). In the Pacific northwest, a recently examined site (Nelson and Coope, 1982) from Discovery Park, Fort Lawton, Seattle, has produced the remains of Cicindela oregona LeConte. A large and varied assemblage accompanies this find which is from sediments previously radiocarbon dated at between 23,000 and 18,000 yr. B.P. The site pre-dates the last major (Vashon) ice advance in the area and suggests a cooler climate with more open 


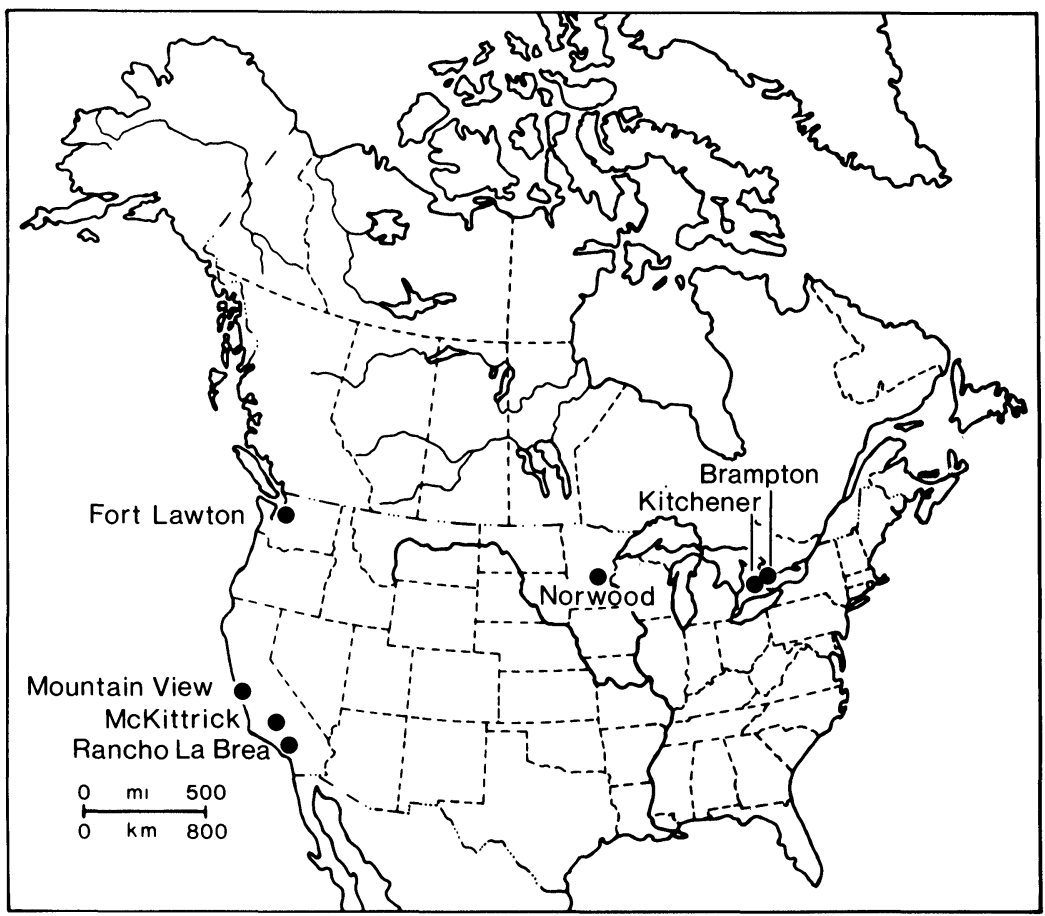

Figure 1. Location of North American sites mentioned in the text.

vegetation, an interpretation similar to that made from another 18,000 year old coleopterous assemblage from Port Moody in southern British Columbia (Miller, Morgan and Hicock, 1982).

In the central eastern section of the continent three sites postdating the retreat of Laurentide ice have produced cicindelid remains. The Norwood site in Minnesota (Ashworth et al., 1981) is a late-glacial kettle which has a sequence of silts overlain by peat

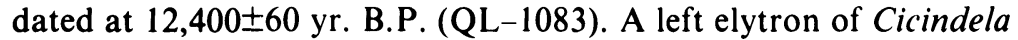
cf. C. sexguttata Fabricius was recovered from the upper silt, an horizon characterized by a number of open ground beetle species. In the Canadian province of Ontario two sites at Kitchener and Brampton contain specifically identified cicindelids. The sites are approximately equivalent in age to the Norwood locality (ca. 12,400 to $12,000 \mathrm{yr}$. B.P.) and both slightly post-date the last major (Port Huron) ice readvance in the region. The Gage Street site, Kitchener, 
produced a solitary, well-preserved mandible of Cicindela repanda Dejean from the basal level of a marl deposit (Schwert, 1978) found in association with open-ground but largely boreal species. The Brampton site near Toronto, is a kettle deposit from which a solitary well-preserved right elytron and mandible fragment of Cicindela limbalis Klug was recovered (Morgan and Freitag, 1982). Once again the cicindelid fragments were associated with a fauna resident today in open ground regions within the boreal zone (Morgan, Morgan and Motz, 1982).

The presence of cicindelids in these early deposits of late Wisconsinan sequences is not surprising. In all cases, with the exception of the California examples, the tiger beetle remains are associated with species which inhabit open ground situations. Undoubtedly the ice merely forced many cicindelid populations southward at the time of maximum advance and they remained there to successfully recolonise sandy terrain after ice retreat. Tiger beetle remains also are present due to the nature of the sediments; the very fine silts and clays which are typical of most of these sequences is ideal for the preservation of the extremely thin elytral chitin found in cicindelids. In coarse sediments, or in sequences which are organic-rich, the detritus would abrade, distort and fragment the remains to a degree where most skeletal parts would become unrecognizable.

In Table 1, we have attempted to compile known fossil Cicindelidae records including those described in this paper, and we have also commented, where appropriate, on some of the early identifications. 


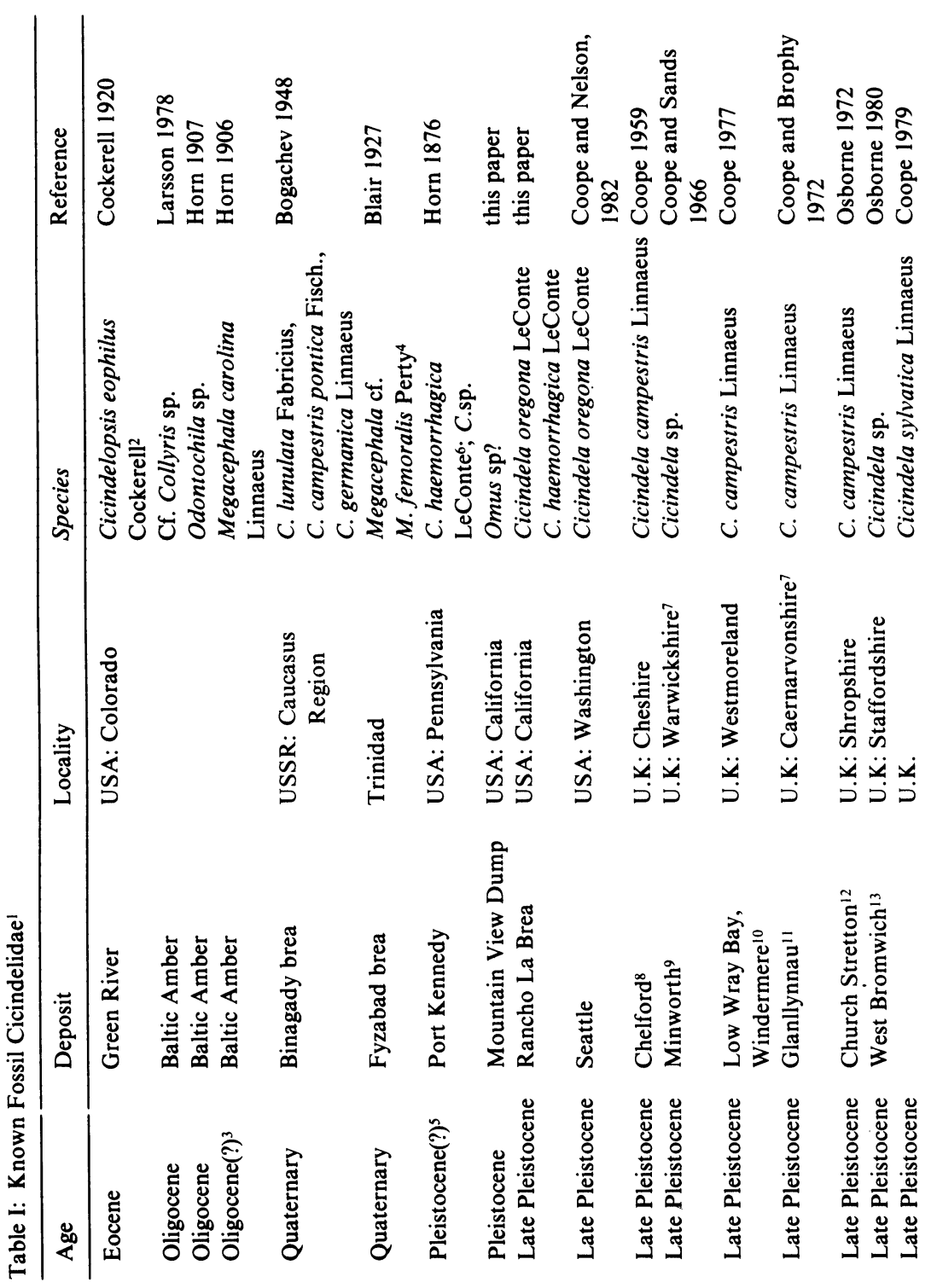




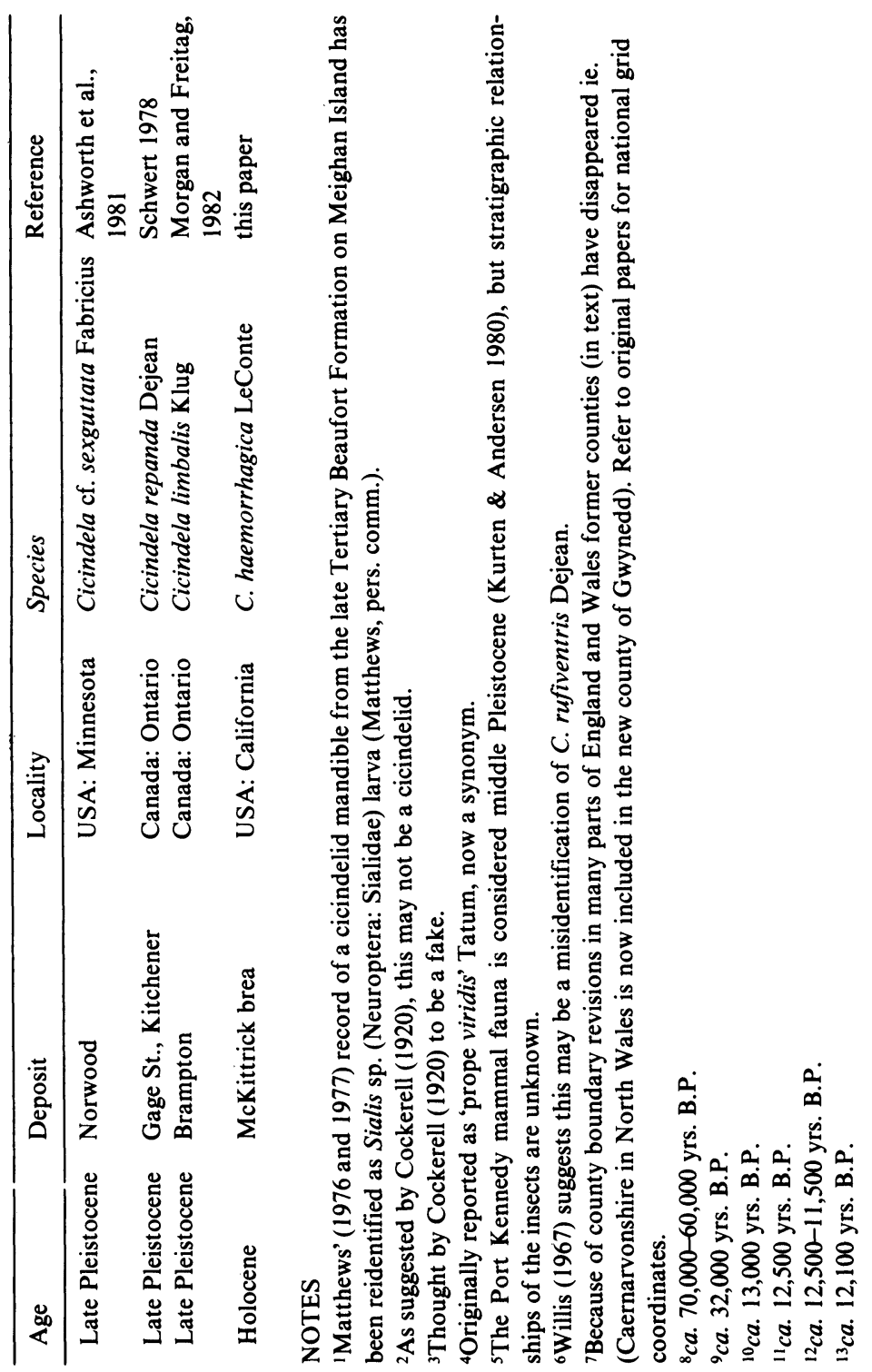




\section{ACKNOWLEDGeMENTS}

We would like to thank C. L. Hogue, P. C. Owen, C. A. Shaw and E. C. Wilson (all of LACM), J. V. Matthews Jr. (Geological Survey of Canada), A. Morgan (University of Waterloo), R. E. Nelson (University of Seattle) and D. P. Schwert (North Dakota State University) for providing specimens and data.

\section{Literature Cited}

Ashworth, A. C., Schwert, D. P., Watts, W. A. and H. E. Wright, Jr. 1981. Plant and Insect fossils at Norwood in south-central Minnesota: A record of Lateglacial succession. Quaternary Res. 16: 66-79.

Blair, K. G. 1927. Insect remains from oil sand in Trinidad. Trans. Ent. Soc. Lond. 75: 137-141.

Bogachev, A. 1948. Fauna of the Binagady asphalt deposit: beetles-Coleoptera. Trudy Estestvenno-Istoricheskii Muzei, Baku 1-2: 137-160. [in Russian].

Cockerell, T. D. A. 1920. Eocene insects from the Rocky Mountains. Proc. U.S. Nat. Mus. 57: 233-260.

Coope, G. R. 1959. A Late Pleistocene insect fauna from Chelford, Cheshire. Proc. Roy. Soc. (London) Ser. B. 151: 70-86.

COOPE, G. R. 1977. Fossil coleopteran assemblages as sensitive indicators of climatic changes during the Devensian (Last) cold stage. Phil. Trans. Roy. Soc. (London) Ser. B. 280: 313-340.

COope, G. R. 1979. The Carabidae of the glacial refuge in the British Isles and their contribution to the post glacial colonization of Scandinavia and the North Atlantic Islands. pp. 407-424 in Erwin, T. L. et al. (ed.), Carabid beetles: their evolution, natural history, and classification. Junk, The Hague.

COOPE, G. R. AND J. A. BROPHY. 1972. Late Glacial environmental changes indicated by a coleopteran succession from North Wales. Boreas 1(2): 97-142.

COOPE, G. R. AND C. H. S. SANDS. 1966. Insect faunas of the last glaciation from the Tame Valley, Warwickshire. Proc. Roy. Soc. (London) Ser. B. 165: 389-412.

HoRN, G. H. 1876. Notes on some coleopterous remains from the bone cave at Port Kennedy, Pennsylvania. Trans. Amer. Ent. Soc. 5: 241-245.

HoRN, W. 1906. Ueber das verkommen von Tetracha carolina L. im preufsischen bernstein und die phylogenie der Cicindela-arten. Deut. Ent. Zeit. pp. 329-336.

HoRN, W. 1907. Brulle's "Odontochila aus dem baltischen Bernstein" und die Phylogenie der Cicindeliden. (Col.). Deut. Ent. Zeit. pp. 461-466.

Kurten, B. AND E. ANDerson. 1980. Pleistocene mammals of North America. Columbia Univ. Press.

LARSSON, S. G. 1978. Baltic amber-a palaeobiological study. Entomonograph 1: 1-192.

Matthews, J. V., JR. 1976. Insect fossils from the Beaufort Formation: Geological and biological significance. Geol. Surv. Can., Paper 76-1B: 217-227. 
Matthews, J. V., JR. 1977 . Tertiary Coleoptera fossils from the North American Arctic. Coleop. Bull. 31: 297-308.

Miller, R. F., Morgan, A. V. ANd S. R. Hicock. 1982. A pre-Vashon insect assemblage from the Fraser lowland, British Columbia. Abs. Vol. VII, AMQUA Conf. Seattle, Wash., 141.

Miller, S. E. AND S. B. PeCK. 1979. Fossil carrion beetles of Pleistocene California asphalt deposits, with a synopsis of Holocene California Silphidae (Insecta: Coleoptera: Silphidae). Trans. San Diego Soc. Nat. Hist. 19: 85-106.

Morgan, A. V. AND A. Morgan. 1980a. Beetle bits-the science of paleoentomology. Geoscience Canada 7: 22-29.

Morgan, A. V. AND A. Morgan. 1980b. Faunal assemblages and distributional shifts of Coleoptera during the Late Pleistocene in Canada and the Northern United States. Can. Ent. 112: 1105-1128.

Morgan, A. V. and R. Freitag. 1982. The occurrence of Cicindela limbalis Klug (Coleoptera: Cicindelidae) in a late-glacial site at Brampton, Ontario. Coleop. Bull. 36:105-108.

Morgan, A. V., Morgan, A. AND J. Motz. 1982. Fossil insect assemblages from the base of a late-glacial sequence near Brampton, Ontario. Prog. with Abs. Geol. Assoc. Can. Annual Meeting, Winnipeg 67.

Nelson, R. E. AND G. R. Coope. 1982. A pre-Vashon (Late Pleistocene) insect fauna from Seattle, Washington. Abs. Vol. VII, AMQUA Conf. Seattle, Wash., 146.

Osborne, P. J. 1972. Insect faunas of Late Devensian and Flandrian age from Church Stretton, Shropshire. Proc. Roy. Soc. (London) Ser. B. 263: 327-367.

OsBorne, P. J. 1980. The Late Devensian-Flandrian transition depicted by serial insect faunas from West Bromwich, Staffordshire, England. Boreas 9: 139-147.

Pierce, W. D. 1947a. Fossil arthropods of California. 13. A progress report on the Rancho La Brea asphaltum studies. Bull. So. Calif. Acad. Sci. 46: 136-138.

PierCe, W. D. 1947b. Fossil arthropods of California. 14. A progress report of the McKittrick asphalt field. Bull. So. Calif. Acad. Sci. 46: 138-143.

SCHWERT, D. P. 1978. Paleoentomological analyses of two postglacial sites in Eastern North America. Unpub. Ph.D. thesis, Univ. of Waterloo. 250 p.

WILLIS, H. L. 1967. Bionomics and zoogeography of tiger beetles of saline habitats in the central United States. Univ. Kansas Sci. Bull. 47: 145-313. 

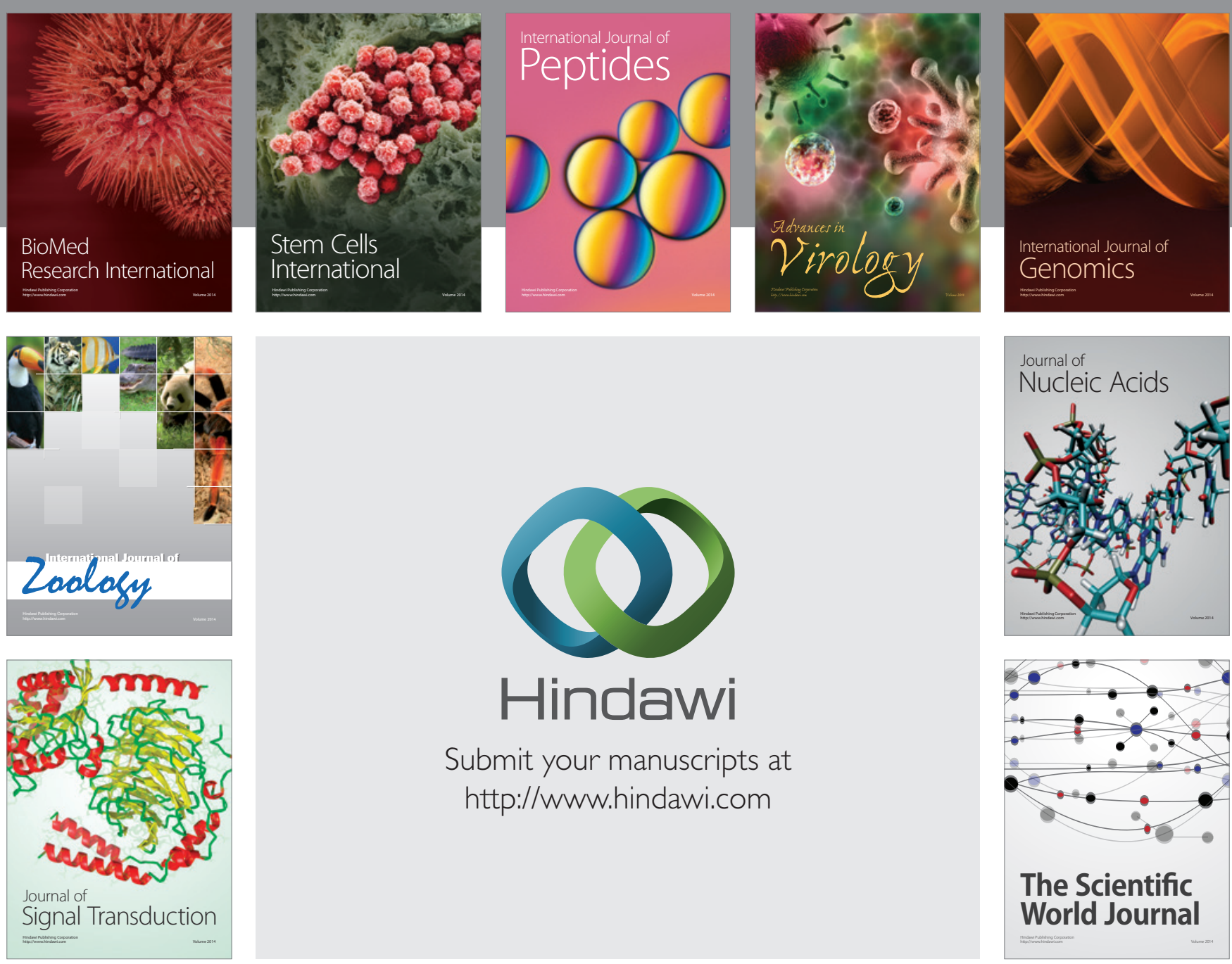

Submit your manuscripts at

http://www.hindawi.com
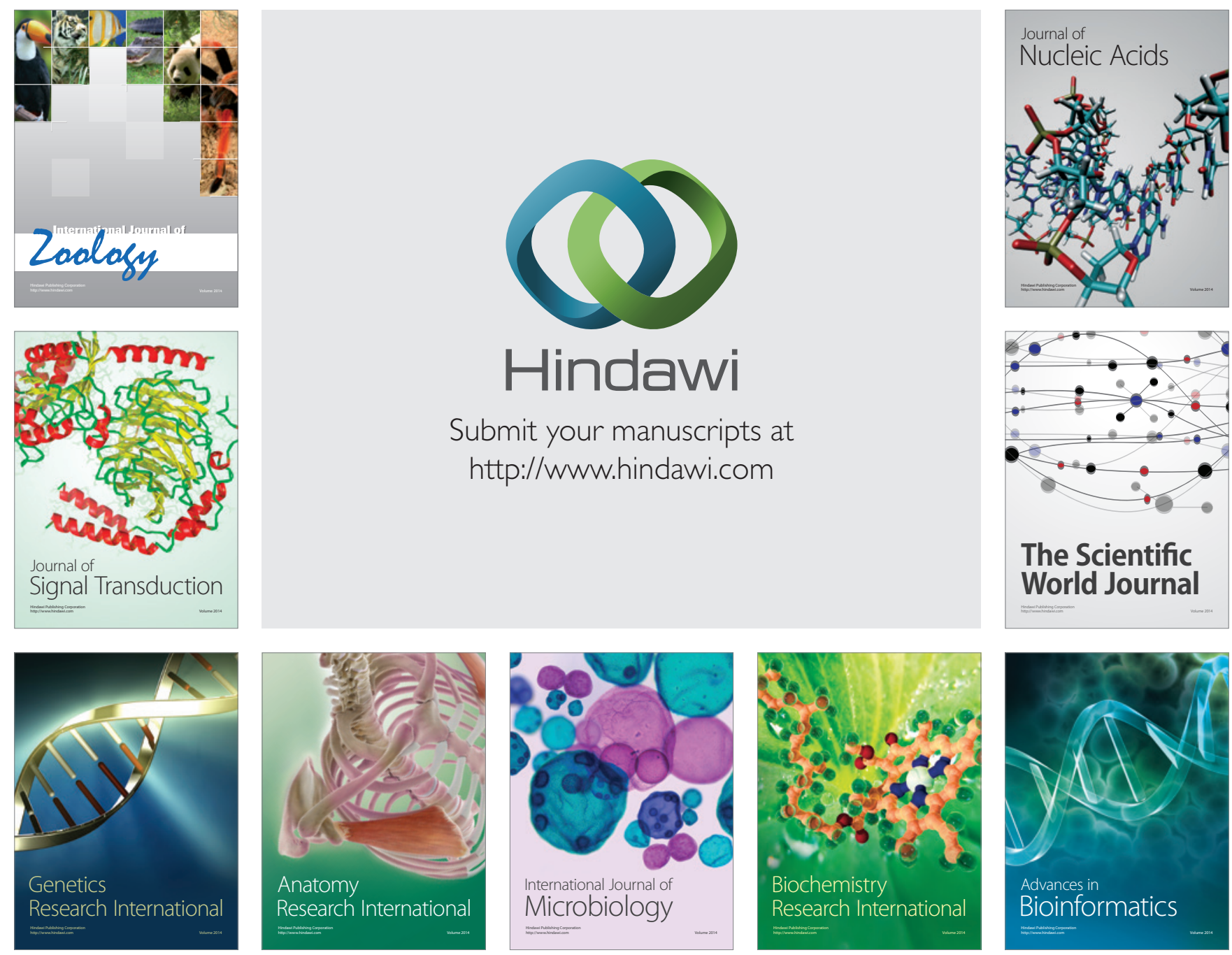

The Scientific World Journal
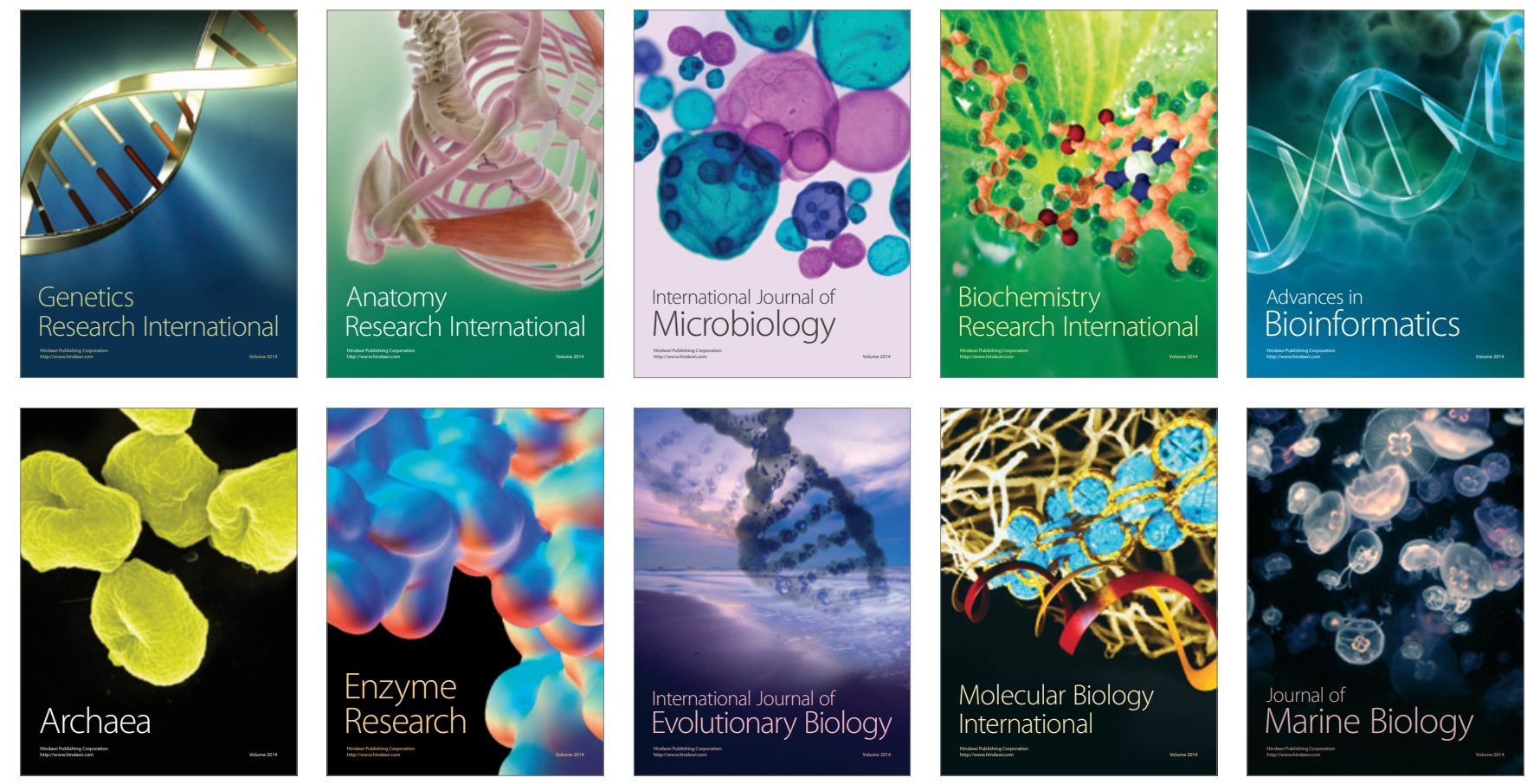